\title{
ВИКОРИСТАННЯ НОВІТНІХ ІНФОРМАЦІЙНИХ ТЕХНОЛОГІЙ ДЛЯ АВТОМАТИЗАЦІЇ ВИЗНАЧЕННЯ ВМІСТУ АЦЕТИЛХОЛІНУ БІОЛОГІЧНИМ МЕТОДОМ
}

\author{
Тернопільський державний медичний університет імені І. Я. Горбачевського
}

\begin{abstract}
У статті наведено новий спосіб визначення вмісту ацетилхоліну біологічним методом в тканинах, який дозволяє максимально зменшити кількість фракторів, що впливають на точність дослідження, а також значно зменшити затрати часу шляхом автоматизації більшої частини дослідження з використанням новітніх інформаційних технологій.
\end{abstract}

Ключові слова: ацетилхолін, визначення ацетилхоліну.

\section{ИСПОЛЬЗОВАНИЕ НОВЕЙШИХ ИНФОРМАЦИОННЫХ ТЕХНОЛОГИЙ ДЛЯ АВТОМАТИЗАЦИИ ОПРЕДЕЛЕНИЯ СОДЕРЖАНИЯ АЦЕТИЛХОЛИНА БИОЛОГИЧЕСКИМ МЕТОДОМ}

\author{
В. Е. Пелых, Р. С. Усинский
}

Тернопольский государственный медицинский университет имени И. Я. Горбачевского

\begin{abstract}
В статье приведён новый способ определения содержания ацетилхолина биологическим методом в тканях, который позволяет максимально уменьшить количество факторов, влияющих на точность исследования, а также значительно уменьшить затраты времени, путем автоматизации большей части исследования с использованием новейших информационных технологий.
\end{abstract}

Ключевые слова: ацетилхолин, определение ацетилхолина.

\section{USAGE OF NEW INFORMATION TECHNOLOGIES FOR AUTOMATIZATION OF ACETYLCHOLINE CONTENT MEASURING BY BIOLOGICAL METHOD}

\author{
V. Ye. Pelykh, R. S. Usynskyi \\ Ternopil State Medical University by I. Ya. Horbachevsky
}

\begin{abstract}
A new method of acetylcholine content in tissues measuring by biological method, allowing greatly decrease amount of factors that influence test accuracy, as well as time spent by automatization of greater part of test with using of new information technologies.
\end{abstract}

Key words: acetylcholine, opredelenit acetylcholine.

Вступ. В умовах зростання патології серцево-судинної системи ведеться активний пошук нових методів іiі лікування. Проводиться активне вивчення стреслімітуючих механізмів, зокрема холінергічної ланки вегетативної нервової системи та її впливу на міокард. Важлива роль у передачі нервового імпульсу при цьому належить нейротрансмітеру ацетилхоліну. У найрізноманітніших дослідженнях проводиться визначення його вмісту в біологічних тканинах, вивчення інтенсивності його синтезу та гідролізу. I надалі найспецифічнішою, точною та дешевою методикою його визначення залишається біологічний ме-

(ㄷ) О. П. Мінцер, С. В. Денисенко, Л. Ю. Бабінцева тод. Суть його полягає у визначенні ступеня скорочення прямого м'яза живота жаби при дії ацетилхоліну. До недавнього часу запис проводили на кімогpaфi, після чого вимірювали вручну висоту підйому пера. Порівнюючи інтенсивність скорочення м'яза на відому та дослідні концентрації, розраховували концентрацію ацетилхоліну. Це досить тривала та громіздка процедура, на якість та точність якої впливають дуже багато чинників $[1,2,3,5]$.

Мета роботи: максимально зменшити кількість факторів, які впливають на точність дослідження, а також значно зменшити затрати часу на визначення 
вмісту AX у міокарді щурів біологічним методом, шляхом автоматизації більшої частини дослідження з використанням новітніх інформаційних технологій (комп'ютеризації процесу).

Методи дослідження. Для визначення вмісту АХ у передсердях і шлуночках серця щурів активно використовується біологічний метод. За його основу взято методику j. Vik a. S. Tucek [5] з наступними модифікаціями і удосконаленнями $[4,6]$. Перед виз- наченням вмісту АХ в міокарді тварин тканини серця проходять спеціальну біохімічну та термічну обробку. [4]. Приготовлені екстракти в подальшому використовуються для досліджень.

Для проведення тестування (рис. 1) прямий м'яз живота жаби (1) поміщають в інкубаційну камеру (2), куди почергово доливають стандартні розчини AX $з$ відомою концентрацією. Для забезпечення ізольованого м'яза киснем через повітропровідну труб-
Puc.1. Стара схема установки для визначення вмісту АХ.

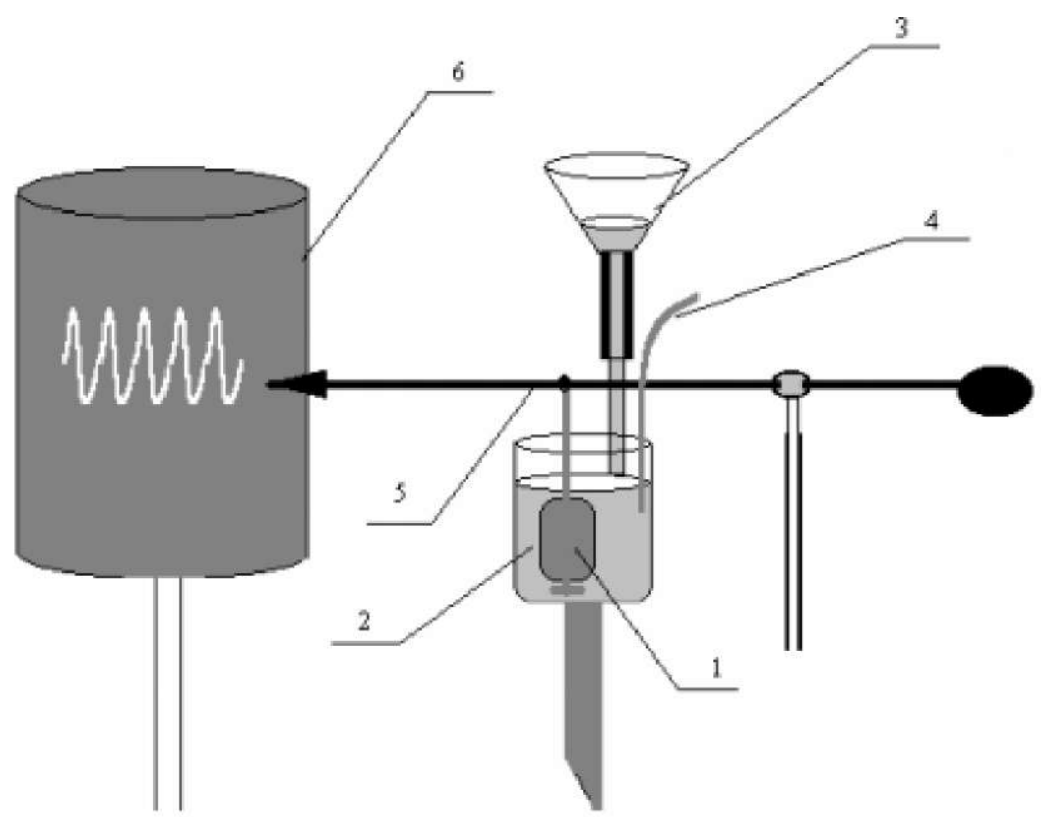

ку (4) здійснюють подачу повітря. Чутливість препарату до розчинів АХ різної концентрації визначають за висотою підйому рівня пера (5) на кімографі (6). 3 метою підвищення чутливості препарату можна використовувати 0,2 \% розчин ацетону [6], який додають до калібрувальних та дослідних розчинів. Ця ж модифікація даної методики дозволяє підвищувати чутливість м'яза шляхом попереднього введення жабам фармакологічного препарату "Цисап" [4], який стимулює виділення AX з нервових закінчень і зменшення його концентрації у зоні контакту з холінорецепторами. Це, в свою чергу, приводить до підвищення чутливості холінорецепторів до екзогенного АХ. Проте всі ці методики впливають лише на чутливість препарату, а запис результатів проводиться застарілим способом - на кімографі. При цьому на результати дослідження впливає ступінь закопченості барабана, натиск пера (значна сила тертя, враховуючи велике плече важеля пера), вібрації при обертанні барабана, а невдала фіксація запису в спиртово-каніфольній суміші іноді зводила нанівець проведені дослідження.

3 метою підвищення ефективності досліджень ми використали новий метод реєстрації результатів (рис. 2). При цьому замість пера та барабана кімографа ми використали оригінальний датчик (7), робота якого грунтується на ефекті Холла. Особливістю конструкції цього датчика є те, що завдяки своєрідному розміщенню власне датчика Холла та неодимового магніту зміна напруги при зміні інтенсивності магнітного поля має практично лінійну залежність від положення важеля (6). Крім того, датчик можна відкалібрувати ще й програмним методом. Для дослідження інтенсивності скорочення препарат прямого м'яза живота жаби за допомого важеля (6) був з'єднаний 3 даним датчиком. При скороченні м'яза у відповідь на введення екстрактів змінюється напруженість магнітного поля і, відповідно, напруга, Зміна напруги підсилюється прецизійним диференціальним операційним підсилювачем і дані з датчика поступають через спеціальний кабель (8) в блок MCU (9). Хоча розміри датчика та блока MCU досить мініатюрні, ми спеціально розділили їх фізично заради унеможливлення будь-якого впливу електронної схеми на реєстрацію сигналу власне датчиком. Блок MCU за допомогою запрограмованого мікроконтроллера оцифровує дані аналогово-цифровим перетворювачем (10 біт), вони усереднюються (по 30 замірів кожних 100 мсек) та переда- 
Puc. 2. Схема нової установки для визначення вмісту АХ (пояснення в тексті).
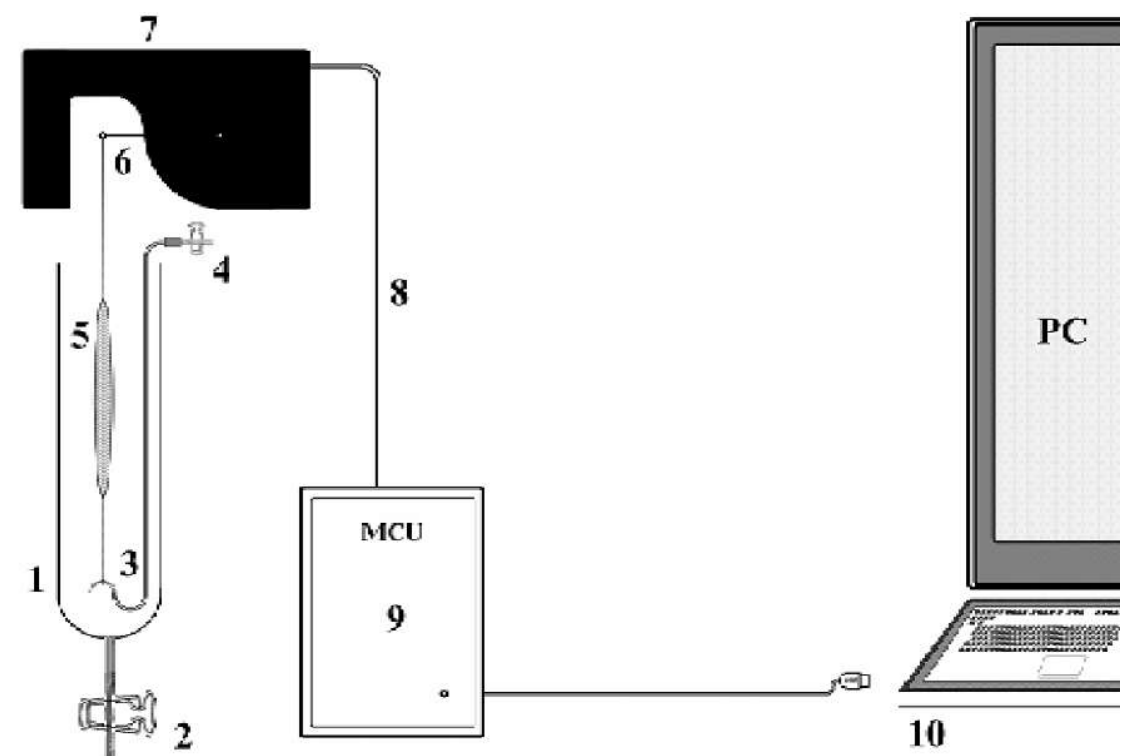

ються на комп'ютер (10) (кожну секунду по 10 усереднень), де остаточно обраховуються, відображаються на екрані в режимі реального часу та за командою оператора записуються у файл спеціально створеною програмою. Отримані результати можна роздруковувати на папері. При цьому ми зразу отримуємо готові конценцентрації дослідних зразків, графік реакції м'яза на відомі та дослідні концентрації. Сама принципова схема була розроблена таким чином, що живлення вона отримувала через USB або COM- порт комп'ютера. Це значно спрощувало їі, оскільки не потрібно було розробляти окреме джерело живлення та зменшувало інтенсивність електромагнітних «шумів». Програмне забезпечення було написане мовою Assembler та РНР. Ще однією особливістю створеної програми є можливість спостереження за процесом

\section{Лiтература}

1. Абазалов Р. А. Содержание ацетилхолини и активность холинэстераз в тканях крыс, развивающихся в условиях различных двигательных режимов / Р. А. Абазалов, Р. Р. Нигматулина, И. Г. Хурамшин // Бюлл. эксперим. биол. и мед. - 1997. - 124, № 12. - С. 625-628.

2. Потіха Н. Я. Вміст ацетилхоліну в міокарді статевонезрілих щурів з експериментальним гіпотиреозом / Н. Я. Потіха //Мед. хімія. - 2004. - Т. 6, № 1. - С. 96-99.

3 Сас Л. М. Зміни холінергічної регуляції серця при експериментальному тироксиновому токсикозі та їх корекція : автореф. дис. на здобуття наукового ступеня канд. мед. дослідження дистанційно по локальній мережі або за допомогою мережі Internet. Також у програмі реалізована можливість використання при аналізі отриманих результатів новітньої технології - так званих «хмаркових обчислень» (cloud computing). Такий підхід до створення програмного забезпечення дозволив виключити необхідність оновлення, оскільки користувач завжди проводить дослідження за допомогою останньої версії аналітичного та обчислювального модуля програми.

Висновок. Відомий спосіб визначення ацетилхоліну в біологічних тканинах вдосконалено шляхом автоматизації більшої частини дослідження з використанням новітніх інформаційних технологій (комп'ютеризації процесу), що робить дослідження більш продуктивним та інформативним.

наук. - Тернопіль, 2004. - 20 с.

4. Файфура В. В. Біологічний метод визначення вмісту ацетилхоліну в міокарді щурів / В. В. Файфура, Л. М. Сас, Н. Я. Потіха, С.В. Дзига // Мед. хімія. - 2004. - Т. 6, № 4. - С. 118-121.

5. Vik J. Distribution of acethylcholine in the auricles of the mammalian heart / J. Vik, S. Tucek// Physiol. bohemoslov. 1961. - Vol. 10, № 1. - P 65-71.

Zeleny A. Action of acetone on the tonic muscle of the frog / A. Zeleny, J. Kozak// Nature. 1958. - 181, № 4619. - P. 13401341 


\section{ІНФОРМАЦІЯ ДЛЯ АВТОРІВ ЖУРНАЛУ «МЕДИЧНА ІНФОРМАТИКА TA IHЖЕНЕРІЯ»}

Програмними цілями науково-практичного журналу «Медична інформатика та інженерія» $\epsilon$ інформування працівників галузі охорони здоров'я України, науковців, викладачів медичних вищих навчальних закладів, співробітників науково-дослідних інститутів медичного і біологічного профілю та громадськості про результати фундаментальних і прикладних досліджень 3 медичної інформатики та інженерії, про сучасні тенденції й процеси інформатизації, що відбуваються в медичній галузі.

Журнал «Медична інформатика та інженерія» приймає до публікації статті, короткі повідомлення, листи до Редакції, що містять оригінальні матеріали досліджень із наступних тем:

1. Інформатизація системи охорони здоров'я.

2. Медичні інформаційні, експертні та інтелектуальні системи.

3. Інформаційні технології системних досліджень в медицині та біології.

4. Проблеми управління в медичних та біологічних системах.

5. Госпітальні інформаційні системи.

6. Оптимізація управління процесами профілактики, діагностики, лікування та реабілітації хворих.

7. Телемедичні технології.

8. Математичне моделювання в медицині, фармакології та біології.

9. Доказова медицина.

10. Медична інженерія та електроніка.

11. Інформаційні технології отримання, збереження, передачі та аналізу медичної та біологічної інформації.

12. Отримання та аналіз медичних та біологічних зображень $\mathrm{i}$ сигналів.

13. Комп'ютерна діагностика захворювань і комп'ютерне прогнозування перебігу та наслідків патологічного процесу.

14. Розробка та використання біометричних методів.

15. Структуризація знань, бази знань, організація пошуку та обробки знань, розповсюдження знань.

16. Сучасні інформаційні технології в медичній та біологічній освіті. Засоби самоосвіти.

17. Теорія та практика дистанційної освіти.

18. Проблеми побудови «суспільства знань».

19. Інформатика, суспільство та національна безпека.

20. Тенденції розвитку медичної та біологічної інформатики та інженерії.

За рішенням редакційної колегії до друку також можуть прийматися огляди 3 актуальних питань медичної інформатики та інженерії, описи перспективних наукових досліджень, рецензії, довідкові та інформаційні матеріали, навчально-методичні матеріали, оголошення щодо наукових заходів і повідомлення рекламного змісту.

Рішення щодо публікації приймається редакційною колегією на підставі результатів рецензування статей. Редакція не бере на себе зобов'язань щодо роз'яснення причин відмови від публікації статті. Надіслані до редакції матеріали авторам не повертаються. Рукописи мають представляти матеріали, що не були опубліковані раніше та не були подані до інших видань.

Вимоги щодо підготовки рукопису

Рукописи повинні надсилатися в двох примірниках українською, російською чи англійською мовою і супроводжуватися файлами тексту (*.rf" або *.doc) та малюнків (*jpg або *.tif) на диску. Електронна та паперова версії статті мають бути ідентичними. Електронна копія може бути надіслана також електронною поштою.
Обсяг оригінальної статті, включаючи таблиці, рисунки, список літератури, резюме, не повинен перевищувати 8 сторінок, обсяг проблемної статті, огляду літератури, лекції - 12 сторінок, короткого повідомлення, рецензії тощо - до 5 сторінок.

До рукопису необхідно додати: (а) супровідний лист від керівника закладу (підрозділу), в якому виконувалася робота 3 рекомендацією до друку та (б) експертний висновок, завірений печаткою, щодо можливості відкритої публікації матеріалів дослідження. За відсутності експертного висновку всю відповідальність за подану інформацію несуть автори. Вартість видавничих послуг відшкодовують автори. Всі автори мають поставити підписи на першій сторінці статті.

Статті, що містять оригінальні матеріали досліджень, мають бути структуровані відповідно до вимог п. 3 Постанови Президії ВАК України № 7-05/1 від 15.01.2003р., оформлені з врахуванням рекомендацій ВАК України щодо публікації матеріалів дисертацій та $з$ дотриманням основних вимог ДСТУ 300895 "Документація. Звіти у сфері науки і техніки. Структура і правила оформлення".

Усі одиниці фізичних величин слід наводити відповідно до Міжнародної системи одиниць (CI) згідно з вимогами групи стандартів ДСТУ 3651-97 "Одиниці фізичних величин"; у разі обгрунтованого використання несистемних одиниць вимірювання слід представити приклад їх переводу в систему СІ. Медична термінологія має відповідати Міжнародній класифікації хвороб (МКХ-10). Назви фірм, приладів, реактивів і препаратів необхідно наводити в оригінальній транскрипції.

Титульний аркуш:

УДК- у верхньому лівому куті.

Назва статті (по центру, півжирним шрифтом, кегль - 16). У назві статті не допускається використання скорочень.

Прізвище та ініціали автора(-ів) (по центру).

Повна назва установи.

Анотація: до 200 слів.

Ключові слова: до вісьмох слів.

Основна частина статті містить наступні розділи: вступ (постановка проблеми у загальному вигляді, її зв'язок із важливими науковими чи практичними завданнями, аналіз останніх опублікованих досліджень, в яких започатковано розв'язання даної проблеми, виділення невирішеної частини загальної проблеми, якій присвячена означена робота).

Мета дослідження. Матеріал і методи дослідження (викладення об'єкта дослідження і методик, опис яких повинен бути достатнім для розуміння їх доцільності і можливості відтворення. У випадку проведення експериментальних досліджень 3 тваринами слід вказувати вид, стать, кількість тварин, методи анестезії при маніпуляціях, пов'язаних із завданням тваринам болю, метод евтаназії. Обов'язковим $є$ зазначення методик статистичного аналізу з обгрунтуванням вибору критеріїв достовірності оцінок). Результати й обговорення (викладається основний фактичний матеріал, проводиться повне обгрунтування отриманих наукових результатів, висловлення власного судження щодо одержаних результатів, його порівняння з тлумаченням подібних даних, наведених іншими авторами). Висновки. Перспективи подальших досліджень (подається бачення автора перспективності подальших шляхів до розв'язання проблеми, висвітленої у роботі). Література (друкується в порядку згадування джерел у тексті, у квадратних дужках). 
Весь текст повинен бути надрукований через 1,5 інтервала, шрифт Times New Roman, кегль - 14, 3 одного боку листа на білому папері формату A4 (1800-2000 друкованих знаків на сторінці). Поля: зліва - 3 см, справа - 1,5 см, зверху та знизу 2,5 см. Текст набирати в одну колонку. Прийнятні формати текстового файлу: MS Word (rtf, doc).

Підзаголовки повинні бути надруковані прописними літерами, півжирним шрифтом.

Рівняння необхідно друкувати у редакторі формул MS Equation Editor, що входить до складу текстового редактора MS Word.

Список літератури повинен формуватися послідовно, в порядку появи посилання в тексті статті. Для оформлення посилань на книги та журнали використовувати відповідні формати, наприклад:

1. Автоматы и разумное поведение / [Амосов Н. М., Касаткин А. М., Касаткина Л. М., Талаев С. А.]. - К.: Наукова думка, 1973. - $374 \mathrm{c}$.

2. Вороненко Ю. В. Технології дистанційного навчання у практичній медицині / Ю. В. Вороненко, О. П. Мінцер // Журнал сучасного лікаря. Мистецтво лікування. - 2005 . - № 7. - С. 8-11.

Рисунки - шириною до 8 см або до 16 см кожен подаються на окремому аркуші. На зворотній стороні вказати номер рисунка, прізвище першого автора, підпис до рисунка (скорочено) та відмітки "Верх", "Низ". Усі рисунки повинні бути пронумеровані в порядку їх появи в тексті. Товщина осі на графіках повинна складати 0,5 pt, товщина кривої - 1,0 pt. Одиниці виміру на осях графіків повинні бути позначені після коми (не в круглих дужках). Рисунки повинні бути якісні, розміри підписів до осей та шкали - 10 pt при вказаних вище розмірах рисунка. Прийнятні графічні формати для рисунків: TIF, JPEG. Рисунки, створені за допомогою програмного забезпечення для математичних і статистичних обчислень, повинні бути перетворені до одного 3 цих форматів.

Ілюстрації приймаються до друку тільки високоякісні. Підписи і символи повинні бути вдруковані. При скануванні слід забезпечити роздільну здатність зображення $300 \mathrm{dpi}$. Пріоритетним $є$ надсилання оригіналів ілюстрацій. Невеликі за об'ємом ілюстрації можна розміщувати по ходу тексту статті.

Фотографії повинні надаватися у вигляді оригінальних контрастних відбитків. У підписах до мікрофотографій вказувати збільшення і метод фарбування матеріалу. Не приймаються до друку негативи, слайди.

Таблиці повинні бути представлені на окремих аркушах. Таблиці повинні мати короткі заголовки і власну нумерацію. Відтворення одного і того ж матеріалу у вигляді таблиць і рисунків не допускається.
Діаграми, графіки бажано створювати у Microsoft Excel.

Підписи до рисунків і таблиць повинні бути надруковані в рукописі після списку літератури на окремому аркуші.

Розширена анотація до статті - подається двома мовами (наприклад, якщо основний текст статті написаний українською мовою, то дві розширені анотації подаються російською та англійською); обсяг - 1 сторінка; містить: (а) назву статті, (б) прізвища та ініціали авторів, (в) електронні адреси авторів, (г) повна назва установи, (д) реферат статті до 400 слів, (є) ключові слова.

Інформація про авторів - подається на окремому аркуші і містить наступні відомості про кожного: прізвище, ім'я, по батькові, науковий ступінь, вчене звання, місце роботи, посада, службова адреса, телефон, факс і електронна пошта. Прізвище автоpa, $з$ яким слід вести листування, має бути підкреслено.

Статті, оформлені без дотримання вищенаведених вимог, не реєструються. У першу чергу друкуються статті передплатників журналу, а також матеріали, що замовлені редакцією. Редакція залишає за собою право виправляти термінологічні та стилістичні помилки; за погодженням з авторами усувати зайві ілюстрації та скорочувати текст.

\section{Рукописи направляти за адресою:}

04112, м. Київ, вул. Дорогожицька, 9,

Національна медична академія післядипломної освіти ім. П.Л. Шупика,

Редакція журналу «Медична інформатика та інженерія» Електронна пошта:miejournal@nmapo.edu.ua

Публікація статей платна. Вартість - 27.50 грн. за 2000 знаків (1 сторінка). Оплата здійснюється після отримання повідомлення про позитивне рішення щодо публікації статті.

Оплату за статті переказувати на розрахунковий рахунок одержувача:

ДВНЗ "Тернопільський державний медичний університет імені І.Я. Горбачевського"

ЄДРПОУ 02010830

p/p 31252273210444 в ГУДКСУ в Тернопільській обл., МФО 838012

В призначенні платежу вказувати: "За друкування статті".

Квитанцію про оплату надсилати на адресу:

Видавництво "Укрмедкнига", 46001, м. Тернопіль, майдан Волі, 1 тел.: (+380352) 43-49-56, факс (+380352) 52-80-09 e-mail:journaltdmy_gmail.com 